\title{
THE EFFECT OF SEASONAL TEMPERATURE ON ENDOGENOUS GUT ENZYME ACTIVITY IN FOUR AIR-BREATHING FISH SPECIES
}

\author{
Goutam Banerjee ${ }^{1,2 *}$, Arun Kumar Ray ${ }^{1}$ \\ ${ }^{1}$ Department of Zoology, Visva Bharati University, Santiniketan, West Bengal, India, 731235 \\ 2 Department of Biochemistry, University of Calcutta, Kolkata, West Bengal, India, 700019 \\ ${ }^{*}$ Corresponding Author, Email: banerjee.goutam2@gmail.com
}

\section{ARTICLE INFO \\ Received: 21 March 2017 \\ Received in revised form: 20 September 2017 \\ Accepted: 21 January 2018 \\ Online first: 13 April 2018}

\begin{abstract}
The digestion process in fish is a complex phenomenon and is accomplished with the help of both endogenous and exogenous enzymes. A wide range of enzymes have been reported in fish and their secretion and concentrations highly depend on feeding habits, gut structure and environmental conditions. In this present investigation, we have demonstrated the activity of two endogenous enzymes (protease and amylase) in four economically important air-breathing fish species (Clarias batrachus, Channa punctatus, Anabas testudineus and Heteropneustes fossilis) at different seasonal temperatures. Our results demonstrated that protease activity was higher in all fish during the month of May, followed by September and December. It was also detected that enzyme activity was higher in the hindgut region (HG) compared to the foregut (FG), which suggests that HG is more active in digestion compared to FG. The optimization of feeding efficiency in aquaculture industries is very important, as the cost of feed is high and its availability is also limited. The information presented may be of importance when developing optimized diets and feeding regimes for the species considered.
\end{abstract}

\section{Keywords:}

Air-breathing fish

Temperature

Enzyme activity
Banerjee, G., Ray, A.K. (2018): The effect of seasonal temperature on endogenous gut enzyme activity in four air-breathing fish species. Croatian Journal of Fisheries, 76, 60-65. DOI: 10.2478/cjf-2018-0007.

\section{INTRODUCTION}

Aquaculture is the fastest growing food production sector in many countries and is of significance in terms of economic growth and diversification. Fish nutrition is an important discipline in aquaculture due to the high cost of feed. On the basis of feed preference, fish can be divided into three broad categories viz. carnivorous, herbivorous and omnivorous, which is directly related to their digestive enzymes (Jhingran, 1997). Thus, supply of feed stuffs is vitally important to obtain maximal growth, immunity and production. Several studies have been conducted regarding fish feed and the efficiency of growth (Aderolu et al., 2010; Ray et al., 2012; Roy et al., 2016). However, most of these studies have highlighted the importance of optimal dietary composition for fish nutrition. The production of catfish in India (mainly in West Bengal, Andhra Pradesh, Assam and Odisha) commenced in 2001. Among several catfish species, Clarias batrachus, Channa punctatus, Anabas testudineus and Heteropneustes fossilis gain special attention due to their high nutritive value. Harvests of cultured catfish in India was 78367 tons in 2001, 132342 tons in 2005 and 212462 
tons in 2010 (Laxmappa, 2015). Due to their high value, farmers are now showing interest in these fish species. According to FAO (2014), the current production of catfish is 10 tons per hectare, however, the government plan is to produce 40 to 50 ton per hectare.

Digestive enzyme activities not only depend on diet composition (protein, carbohydrate and lipid), but also environmental conditions such as temperature and water pH (Hofer, 1979; Xiong et al., 2011). Temperature is a critical factor in maintaining fish physiological control processes and thus has direct effects on digestion and metabolism in fish (Savoie et al., 2008). It is already well established that temperature and its seasonal variations control different functions such as swimming activity, digestive enzyme secretion, metabolic rate and oxygen consumption in fish. However, detailed information regarding the seasonal temperature variability of enzymes and their effect on the nutrition of economically important air-breathing fish species is not available. Along with exogenous enzymes (mainly produced by gut bacteria), endogenous enzymes play a vital role in digestion. Among several enzymes, proteases are the most crucial in carnivorous fish, as their diet contains protein-rich material. However, carnivorous species also express endogenous amylase activity (Krogdhal et al., 2005; Srichanum et al., 2012). Thus, the aim of the present investigation was to explore the endogenous protease and amylase activities of four fish species at different seasonal temperatures.
Table 1. The feeding habit of the fish species examined (Jhingran, 1997)

\begin{tabular}{ll}
\hline Fish species & Feeding habit \\
\hline Channa punctatus & $\begin{array}{l}\text { Small fish, Zooplankton, } \\
\text { insects }\end{array}$ \\
Clarias batrachus & $\begin{array}{l}\text { Insect, worms, shrimps } \\
\text { Insect, worms, shrimps }\end{array}$ \\
Heteropneustes fossilis & Small fish, insects, water \\
& fleas, debris \\
\hline
\end{tabular}

\section{MATERIALS AND METHODS}

\section{Fish examined}

Four adult Indian air-breathing fish species, namely walking catfish Clarias batrachus, snakehead Channa punctatus, climbing perch Anabas testudineus and stinging catfish Heteropneustes fossilis were used in the present study (Table 1). The fish were obtained from a local fish farm near Santiniketan, West Bengal, India $\left(23^{\circ} 41^{\prime} 30^{\prime \prime} \mathrm{N}\right.$ latitude and $87^{\circ} 41^{\prime} 20^{\prime \prime} \mathrm{E}$ longitude) and maintained in $100 \mathrm{~L}$ tanks. Four different fish species (50 each) were kept in four different tanks. Fish were fed twice daily at 10:00 and 18:00 h. Holding parameters (water quality, feeding time and feeds) were constant throughout the experiment.

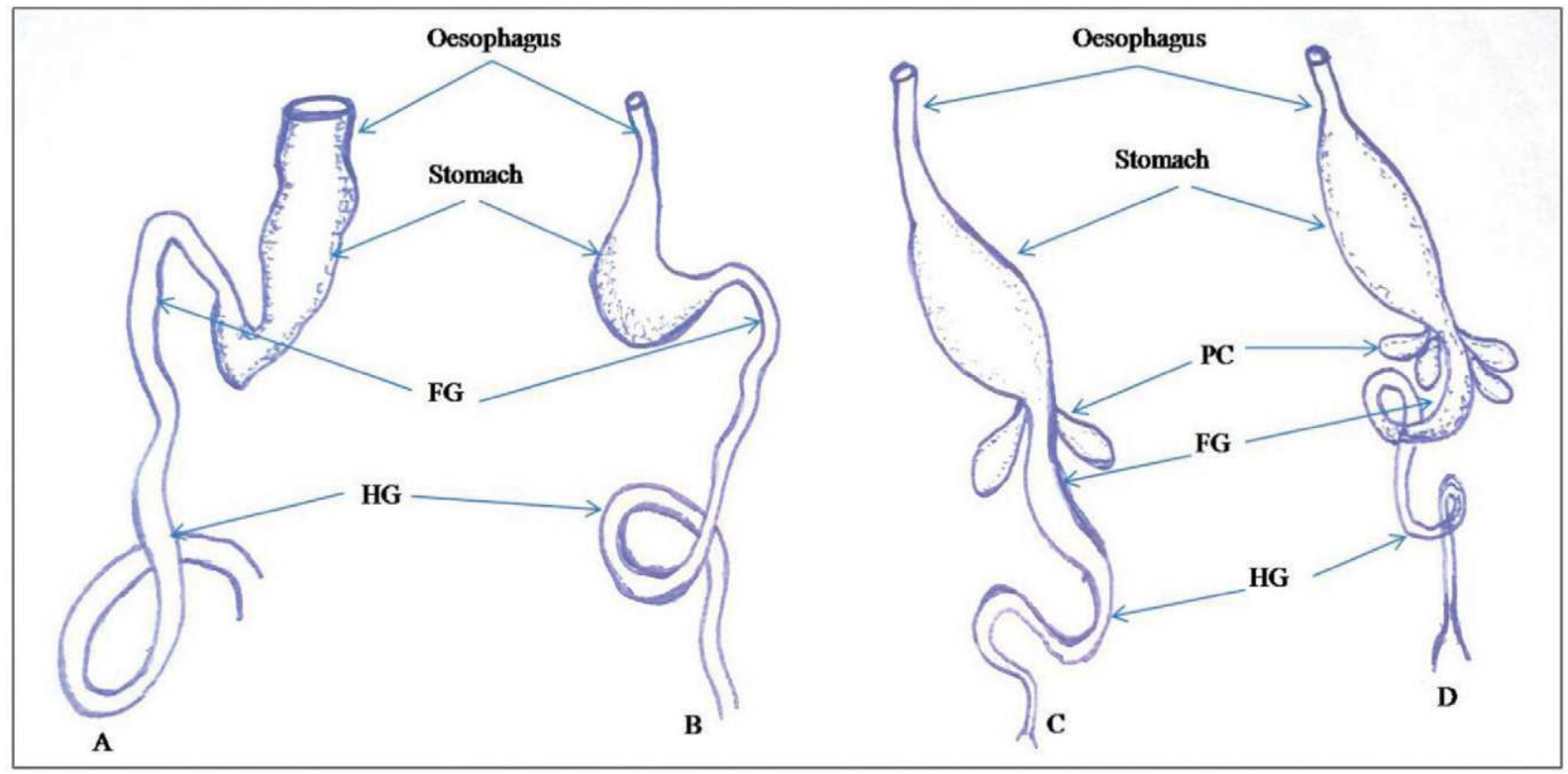

Fig 1. Represents the schematic sketch of the digestive tracts of these four selected fish species. A, B, C and D represent the digestive tract of $C$. batrachus, $H$. fossilis, $C$. punctatus and A. testudineus, respectively. FG-foregut, HG-hindgut, PCpyloric caeca. 


\section{Sampling time and sample preparation}

May $\left(40^{\circ} \mathrm{C}\right.$ to $\left.44^{\circ} \mathrm{C}\right)$, September $\left(25^{\circ} \mathrm{C}\right.$ to $\left.32^{\circ} \mathrm{C}\right)$ and December $\left(6^{\circ} \mathrm{C}\right.$ to $\left.15^{\circ} \mathrm{C}\right)$ were selected for sampling months. In order to examine activity of the endogenous digestive enzymes, the gut was collected from fish immediately after killing and washed (using $20 \mathrm{mM}$ phosphate buffer, $\mathrm{pH}$ 6.8) thoroughly to remove gut contents. The gut was divided into two parts (Fig. 1); foregut (FG) and hindgut (HG), homogenized separately in sterile chilled phosphate buffer (0.1 M, pH 7.2), centrifuged at $4^{\circ} \mathrm{C}(8000 \times g$, for $15 \mathrm{~min})$, and supernatant was collected for further studies. Protein content was measured according to the method of Lowry et al. (1951).

\section{Enzyme activity}

Protease and amylase activities were assessed forgut samples using the methods of Walter (1984) and Bernfeld (1955), respectively. In brief, protease activity was determined using casein as a substrate. The colour developed was measured spectrophotometrically at $273 \mathrm{~nm}$. The enzyme activity was expressed as the microgram tyrosine released/mg protein/ unit time. Similarly, amylase activity was determined using starch as a substrate. The colour developed was measured spectrophotometrically at $560 \mathrm{~nm}$. The enzyme activity was expressed as the microgram maltose released /mg protein/ unit time. The $\mathrm{pH}$ of the gut of these fish species ranged from 6.8 to 7.0. All the assays were done at $\mathrm{pH}$ 7.0. The assay temperature was maintained as per water temperature of the tank.

\section{Statistical analysis}

In order to analyze the variance, one-way ANOVA was used (Origin 6.1) along with Duncan's multiple range tests for significance at $p<0.05$. All experiments were done in triplicate (three fish per sampling) and data was reported as the mean value \pm standard error.

\section{RESULTS}

The endogenous protease and amylase activities of the four species studied are given in Table 2 and Table 3, respectively. In case of $C$. punctatus, the protease and amylase activities were recorded to be highest in the month of May in the FG $(7.27 \pm 0.19 \mu \mathrm{g}$ of tyrosine liberated/ $\mathrm{mg}$ protein/ $\mathrm{min}$ ) and $\mathrm{HG}(4.0 \pm 0.11 \mu \mathrm{g}$ of maltose liberated/ $\mathrm{mg}$ protein/ $\mathrm{min}$ ) gut regions, respectively. Lowest protease (FG $3.41 \pm 0.13 \mu \mathrm{g}$ of tyrosine liberated/ $\mathrm{mg}$ protein/ $\mathrm{min}$ and $\mathrm{HG} 2.08 \pm 0.11 \mu \mathrm{g}$ of tyrosine liberated/ $\mathrm{mg}$ protein/ $\mathrm{min}$ ) and amylase (FG $1.89 \pm$ $0.06 \mu \mathrm{g}$ of maltose liberated/ $\mathrm{mg}$ protein/ $\mathrm{min}$ and HG 1.76 $\pm 0.06 \mu \mathrm{g}$ of maltose liberated/ $\mathrm{mg}$ protein/ $\mathrm{min}$ ) activities were detected during the winter season/ December (Table

Table 2. Endogenous protease activity of the selected fish species at different seasons

\begin{tabular}{lccccccc}
\hline \hline \multirow{2}{*}{ Fish species } & \multicolumn{4}{c}{ Seasonal protease activity (U1) } & \multicolumn{2}{c}{ September } \\
& FG December & HG & FG & May & HG & FG & HG \\
\hline Channa punctatus & $3.41 \pm 0.13^{\mathrm{b}}$ & $2.08 \pm 0.11^{\mathrm{b}}$ & $7.27 \pm 0.19^{\mathrm{a}}$ & $4.43 \pm 0.09^{\mathrm{a}}$ & $6.34 \pm 0.11^{\mathrm{a}}$ & $4.1 \pm 0.8^{\mathrm{a}}$ \\
Clarias batrachus & $1.23 \pm 0.07^{\mathrm{c}}$ & $2.98 \pm 0.06^{\mathrm{b}}$ & $3.53 \pm 0.09^{\mathrm{a}}$ & $5.26 \pm 0.10^{\mathrm{a}}$ & $2.89 \pm 0.04^{\mathrm{b}}$ & $5.37 \pm 0.09^{\mathrm{a}}$ \\
Heteropneustes fossilis & $0.82 \pm 0.02^{\mathrm{b}}$ & $1.69 \pm 0.04^{\mathrm{b}}$ & $1.69 \pm 0.05^{\mathrm{a}}$ & $2.81 \pm 0.07^{\mathrm{a}}$ & $1.58 \pm 0.05^{\mathrm{a}}$ & $2.73 \pm 0.07^{\mathrm{a}}$ \\
Anabas testudineus & $0.97 \pm 0.02^{\mathrm{b}}$ & $2.69 \pm 0.03^{\mathrm{b}}$ & $2.09 \pm 0.03^{\mathrm{a}}$ & $4.27 \pm 0.06^{\mathrm{a}}$ & $1.99 \pm 0.05^{\mathrm{a}}$ & $3.98 \pm 0.03^{\mathrm{a}}$ \\
\hline \hline
\end{tabular}

Different alphabets indicates significant difference at $p<0.05$ level. FG-Foregut, HG-Hindgut

$\mathrm{U} 1$ - $\mu \mathrm{g}$ of tyrosine liberated/ $\mathrm{mg}$ protein/ min

Table 3. Endogenous amylase activity of the selected fish species at different seasons

\begin{tabular}{ccccccc}
\hline \hline \multirow{2}{*}{ Fish species } & \multicolumn{2}{c}{ Seasonal amylase activity (U2) } & \multicolumn{2}{c}{ September } \\
& FG & December & Hay & FG & HG & FG \\
\hline Channa punctatus & $1.89 \pm 0.06^{\mathrm{c}}$ & $1.76 \pm 0.06^{\mathrm{b}}$ & $3.42 \pm 0.09^{\mathrm{a}}$ & $4.0 \pm 0.11^{\mathrm{a}}$ & $2.61 \pm 0.07^{\mathrm{b}}$ & $3.55 \pm 0.05^{\mathrm{a}}$ \\
Clarias batrachus & $1.08 \pm 0.04^{\mathrm{b}}$ & $2.93 \pm 0.07^{\mathrm{b}}$ & $3.83 \pm 0.07^{\mathrm{a}}$ & $4.47 \pm 0.08^{\mathrm{a}}$ & $3.44 \pm 0.06^{\mathrm{a}}$ & $4.03 \pm 0.09^{\mathrm{a}}$ \\
Heteropneustes fossilis & $2.07 \pm 0.07^{\mathrm{b}}$ & $2.31 \pm 0.07^{\mathrm{b}}$ & $4.34 \pm 0.05^{\mathrm{a}}$ & $3.72 \pm 0.03^{\mathrm{a}}$ & $4.17 \pm 0.02^{\mathrm{a}}$ & $2.51 \pm 0.03^{\mathrm{b}}$ \\
Anabas testudineus & $2.06 \pm 0.04^{\mathrm{b}}$ & $2.27 \pm 0.03^{\mathrm{c}}$ & $3.52 \pm 0.02^{\mathrm{a}}$ & $3.85 \pm 0.03^{\mathrm{a}}$ & $3.29 \pm 0.07^{\mathrm{a}}$ & $3.17 \pm 0.04^{\mathrm{b}}$ \\
\hline \hline
\end{tabular}

Different alphabets indicates significant difference at $\mathrm{p}<0.05$ level. FG-Foregut, HG-Hindgut

$\mathrm{U} 2$ - $\mu \mathrm{g}$ of maltose liberated/ $\mathrm{mg}$ protein/ $\mathrm{min}$ 
2 and 3). On the other hand, the protease activity in both C. batrachus and $H$. fossilis varied greatly during the month of December, May and September. Highest amylase activity was recorded in the HG region of $C$. batrachus $(4.47 \pm 0.08$ $\mu \mathrm{g}$ of maltose liberated/ $\mathrm{mg}$ protein/ $\mathrm{min}$ ) during the month of May (Table 3 ). Whereas, highest protease activity was quantified in the $\mathrm{HG}$ region during the month of September (5.37 $\pm 0.09 \mu \mathrm{g}$ of tyrosine liberated/ $\mathrm{mg}$ protein/ $\mathrm{min}$ ), followed by $5.26 \pm 0.10 \mu \mathrm{g}$ of tyrosine liberated/ $\mathrm{mg}$ protein/ min during May (Table 2). However, this difference was not significant at $p>0.05$. Conversely, highest protease and amylase activities were measured in the HG region (2.81 $\pm 0.07 \mu \mathrm{g}$ of tyrosine liberated/ $\mathrm{mg}$ protein/ $\mathrm{min}$ and $3.72 \pm$ $0.03 \mu \mathrm{g}$ of maltose liberated/ $\mathrm{mg}$ protein/ min, respectively) during May. The trend in enzyme activity in $A$. testudineus was quite similar to the other species with highest protease and amylase activities being recorded in the $\mathrm{HG}$ region during the month of May $(4.27 \pm 0.06 \mu g$ of tyrosine liberated $/ \mathrm{mg}$ protein/ $\mathrm{min}$ and $3.85 \pm 0.03 \mu \mathrm{g}$ of maltose liberated/ $\mathrm{mg}$ protein/ $\min$, respectively), followed by September and December (Table 2 and 3).

\section{DISCUSSION}

The digestive physiology of the fish species examined herein is alike, probably reflecting their similar feeding habits. The digestive system starts with the esophagus, followed by stomach, pyloric caeca, foregut and hindgut (Shahin et al., 2013), however, the number of pyloric caeca varied from one fish species to another. For example, $C$. punctatus and A. testudineus have two and four pyloric caeca, respectively (Ray and Moitra, 1982; Banerjee et al., 2015), whereas, $C$. batrachus and $H$. fossilis do not possess pyloric caeca (Raji and Norouzi, 2010; Abidi and Parwez, 2015). The digestive enzymes in these fish species usually work better at neutral (6.8-7.0) to slightly alkaline $\mathrm{pH}(>7.0)$ (Gupta, 1981). The fish species used in this investigation have great economic importance, particularly $C$. batrachus which has global demand with a market value $\approx$ US\$800000 due to its digestible protein, high mineral content and adequate cholesterol level (Debnath, 2011). Endogenous enzymes play a critical role in digestion and metabolism, however, a significant amount of exogenous enzyme is also contributed by gut bacteria (Ray et al., 2012; Banerjee and Ray, 2016). In general, the activity of amylase is higher in omnivorous fish compared to carnivorous species, whereas higher protease activity has been reported for carnivorous teleosts (Krogdahl et al., 2005; Ray et al., 2012). Endogenous enzyme activities have been reported for numerous fish species including European perch Perca fluviatilis, Atlantic cod Gadhus morhura, Atlantic salmon Salmo salar and Arctic charr Salvelinus alpinus (Torrissen and Shearer, 1992; Lemieux et al., 1999; Langeland et al., 2013), but fewer studies have related endogenous enzyme activities to seasonal temperature variations (Hofer, 1979a,b; Kofuji et al., 1985). Previously, Savoie et al. (2008) mentioned the relation between temperature and metabolic rate in spotted wolfish (Anarhichas minor), and clearly indicated that trypsin and glycolytic enzymes had positive and negative correlation with temperature, respectively. Because of high feed costs, fish nutrition is an important subject in the animal feed and aquaculture sectors.

In general, two types of fermentation/digestion occur in the animal gut: foregut digestion and hindgut digestion. Gut bacterial enzymes (exogenous), along with endogenous enzymes, play a critical role in digestion. Here we divided the entire gut into foregut and hindgut to determine the digestion efficiency of the two parts. The results clearly demonstrated that the HG was more active in digestion when compared to the FG. In the present investigation, fluctuations in endogenous protease and amylase activities were recorded at different seasonal temperatures. Accordingly, diets used during production should be provided according to digestive efficiency. Thus, as demonstrated herein, protein rich diet requirement would be greater between April and October (temperature variation from $25^{\circ} \mathrm{C}$ to $44^{\circ} \mathrm{C}$ ). Furthermore, it was also observed that $\mathrm{HG}$ region returned higher enzyme activity when compared to the FG region during digestion. The information regarding the endogenous enzyme profiles at different temperatures might be important in diet formulation and feeding optimization.

\section{ACKNOWLEDGEMENTS}

We are very much thankful to Visva Bharati University, Santiniketan, West Bengal, India for providing necessary support. We are also grateful to the University Grants Commission, New Delhi, India for financial support to the research project.

\section{SAŽETAK}

\section{UTJECAJ SEZONSKIH TEMPERATURA NA AKTIVNOST ENDOGENIH PROBAVNIH ENZIMA KOD ČETIRI VRSTE RIBA KOJE MOGU UDISATI ZRAK}

Probava u riba je složen proces koji se obavlja uz pomoć endogenih i egzogenih enzima. Zabilježen je širok raspon vrsta enzima kod riba, a njihovo lučenje i koncentracije su izrazito ovisne o hranidbenim navikama, strukturi crijeva te okolišnim uvjetima. U ovom istraživanju, utvrđena je aktivnost dva endogena enzima (proteaza i amilaza) u četiri ekonomski važne vrste riba koje mogu udisati zrak (Clarias batrachus, Channa punctatus, Anabas testudineus i Heteropneustes fossilis) pri različitim sezonskim temperaturama. Rezultati su 
ukazali na višu aktivnost proteaze kod svih istraživanih riba tijekom mjeseca svibnja, nakon čega slijede rujan i prosinac. Također, indicirana je viša enzimska aktivnost u području stražnjeg crijeva (HG) u usporedbi s prednjim crijevom (FG), što upućuje da je HG aktivnije u probavnim aktivnostima od FG. Optimizacija učinkovitosti hranidbe $u$ industriji akvakulture je vrlo važna jer su troškovi hrane visoki a njena dostupnost ograničena. Prikazane informacije u radu mogu poslužiti pri razvoju optimalnih hranidba i režima hranjenja za razmatrane vrste.

Ključne riječi: Ribe koje mogu udisati zrak, temperatura, enzimska aktivnost

\section{REFERENCES}

Abidi, S., Parwez, I. (2015): Histomorphology of oesophagus and histochemical characterization of oesophageal mucin of the catfish Heteropneustes fossilis. International Journal of Fisheries and Aquatic Studies, 3, 199-204.

Aderolu, A.Z., Seriki, B.M., Apatira, A.L., Ajaegbo, C.U. (2010): Effects of feeding frequency on growth, feed efficiency and economic viability of rearing African catfish Clarias gariepinus (Burchell, 1822) fingerlings and juveniles. African Journal of Food Science, 4, 286 - 290.

Banerjee, G., Nandi, A., Dan, S.K., Ghosh, P., Ray, A.K. (2015): Electron microscopical and bacteriological study on the epithelial associated bacteria in the pyloric caeca of murrel Channa punctatus (Bloch). International Journal of Fisheries and Aquatic Studies, 2, 108-113.

Banerjee, G., Ray, A.K. (2016): Bacterial symbiosis in the fish gut and its role in health and metabolism. Symbiosis, 72, 1, 1-11.

Bernfeld, P. (1955): Amylase [alpha] and [beta]. In: Kolowick S.P., Kaplan N.O. (eds.) Methods of enzymology. Academic Press, New York, USA, 149-150.

Debnath, S. (2011): Clarias batrachus, the medicinal fish: An excellent candidate for aquaculture \& employment generation. International Conference on Asia Agriculture and Animal. Singapoore, 13 IACSIT Press, 32-37.

FAO (2014): National Aquaculture Sector Overview India, Rome, 14.

Gupta, S.B.C. (1981): Food and feeding habits and physiology of digestion in certain riverine teleosts. Proceedings of the Indian National Science Academy, B47, 837-844.

Hofer, R. (1979a): The adaptation of digestive enzymes to temperature, season and diet in the roach, Rutilus rutilus and rudd Scardinius erythrophthalmus; Amylase. Journal of Fish Biology, 14, 565-572.

Hofer, R. (1979b): The adaptation of digestive enzymes to temperature, season and diet in the roach, Rutilus rutilus and rudd Scardinius erythrophthalmus; Proteases. Journal of Fish Biology, 15, 373-379.
Jhingran, V.G. (1997) Fish and Fisheries of India, 3rd ed. Hindustan Publishing Corporation, New Delhi, India, 335337.

Kofuji, P.Y., Akimoto, A., Hiosokawa, H., Masumoto, T. (1985): Seasonal changes in proteolytic enzymes of yellowtail Seriola quinqueradiata (Temminck \& Schlegel; Carangidae) fed extruded diets containing different protein and energy levels. Aquaculture Research, 36, 696-703.

Krogdahl, A., Hemre, G.-I., Mommsen, T.P. (2005): Carbohydrate in fish nutrition: digestion and absorption in postlarval stages. Aquaculture Nutrition, 11, 103-122.

Langeland, M., Lindberg, J.E., Lundh, T. (2013): Digestive enzyme activity in Eurasian perch (Perca fluviatilis) and Arctic charr (Salvelinus alpinus). Aquaculture Research and Development, 5, 208.

Laxmappa, B. (2015): Catfish production in India: present status and prospects. International Aquafeed, 5, 18-19.

Lemieux, H., Blier, P., Dutil, J.D. (1999): Do digestive enzymes set a physiological limit on growth rate and food conversion efficiency in the Atlantic cod (Gadus Morhua)? Fish Physiology and Biochemistry, 20, 293-303.

Lowry, O.H., Rosebrough, N.J., Farr, A.L., Randall, R.J. (1951): Protein measurement with the folin phenol reagent. Journal of Biological Chemistry, 193, 265-275.

Ray, A.K., Moitra, S.K. (1982): On the morpho-histology of the alimentary tract in the Indian climbing perch Anabas testudineus (Bloch) in relation to food and feeding habits. Gegenbaurs Morphologisches Jahrbuch, 128, 778-798.

Raji, A.R., Norouzi, E. (2010): Histological and histochemical study on the alimentary canal in Walking catfish (Claris batrachus) and piranha (Serrasalmus nattereri). Iranian Journal of Veterinary Research, Shiraz University, 11, 255-261.

Ray, A.K., Ghosh, K., Ringø, E. (2012): Enzyme-producing bacteria isolated from fish gut: a review. Aquaculture $\mathrm{Nu}-$ trition, 18, 465-492.

Roy, T., Dan, S.K., Banerjee, G., Nandi, A., Ghosh, P., Ray, A.K. (2016): Comparative efficacy of phytase from fish gut bacteria and a commercially available phytase in improving the nutritive value of sesame oilseed meal in formulated diets for rohu, Labeo rohita (Hamilton) fingerlings. Acta Icthyologica et Piscatoria, 46, 9-23.

Savoie, A., Le François, N.R., Cahu, C., Blier, P.U. (2008): Metabolic and digestive enzyme activity profiles of newly hatched spotted wolffish (Anarhichas minor Olafsen): effect of temperature. Aquaculture Research, 39, 382-389.

Shahin, M.I.H., Chandra, K.J., Das, D.R., Khalil, S.M.I. (2013): Morphology and histopathology of alimentary canal of Clarias batrachus (Linnaeus) and Heteropneustes fossilis (Bloch). International Research Journal of Applied Life Sciences, 2, 11-20.

Srichanun, M., Tantikitti, C., Vatanakul, V., Musikarune, P. (2012): Digestive enzyme activity during ontogenetic de- 
velopment and effect of live feed in green catfish larvae (Mystus nemurus Cuv. \& Val.). Songklanakarin Journal of Science and Technology, 34, 247-254.

Torrissen, K.R., Shearer, K.D. (1992): Protein digestion, growth and food conversion in Atlantic salmon and Arctic charr with different trypsin-like isozyme patterns. Journal of Fish Biology, 41, 409-415.
Walter, H.E. (1984): Methods of enzymatic analysis. Verlag Chemie, Weinheim, Germany.

Xiong, D.M., Xie, C.X., Zhang, H.J., Liu, H.P. (2011): Digestive enzymes along digestive tract of a carnivorous fish Glyptosternum maculatum (Sisoridae, Siluriformes). Journal of Animal Physiology and Animal Nutrition, 95, 56-64. 